\title{
Ductile extensional shear zones in the lower crust of a passive margin
}

\author{
CamilleClerc ${ }^{\mathrm{a}}$ LaurentJolivet $^{\mathrm{b}}$ Jean-ClaudeRingenbach \\ a CNRS/INSU, ISTO, UMR7327, 45071 Orléans, France \\ Université d'Orléans, ISTO, UMR7327, 45071 Orléans, France \\ Total SA, Structural Geology Department, CSTJF, 64000 Pau, France
}

\section{Highlights}

- Outstanding seismic profile offering a rare view of the crust down to $40 \mathrm{~km}$ depth.

- Unprecedented image of ductile deformation at the base of the continental crust.

- Simple shear-dominated deformation at the scale of the whole continental crust.

- Top-to-the continent sense of shear in agreement with the formation of the SDR.

\section{Abstract}

We describe and interpret an unpublished set of ION Geophysical seismic reflection profile showing strong organized seismic reflectors at the base of the continental crust of the Uruguayan volcanic rifted margin. We distinguish two main groups of reflectors in the lowermost continental crust. A first group, at depths ranging from $32 \mathrm{~km}$ below the continent to $16 \mathrm{~km}$ in the continent-ocean transition, comprises reflectors continuous over tens of kilometers, peculiarly visible near the mantle-crust boundary. A second group of reflectors dipping toward the ESE (oceanward) is widely distributed in the lower crust. These reflectors are slightly curved and tend to merge and become sub-parallel with the first group of reflectors. Together they draw the pattern of thick shallow-dipping top-to-the continent shear zones affecting the lower continental crust. Such sense of shear is also consistent with the continentward dip of the normal faults that control the deposition of the thick syn-tectonic volcanic formations (SDR). A major portion of the continental crust behaved in a ductile manner and recorded a component of top-to-the continent penetrative simple shear during rifting indicative of a lateral movement between the upper crust and the mantle.

Keywords : passive margin, volcanic margin, ductile deformation, SDR, lower crust, shear zone

\section{Introduction: the mechanics of the crust at rifted margins}

The behavior of the lower crust in extensional settings is still poorly understood and may be variable from place to place. Based on observations from the Alpine inverted margins, some authors propose a brittle, strong mafic and felsic lower continental crust constituted of 
gabbros and dry granulites (Mohn et al., 2012). Although the lithology of the lower crust seems well constrained for the Alpine Tethys system (Müntener et al., 2000; Mohn et al., 2012), this might not be the case along other margins worldwide. Due to its strong lateral and vertical heterogeneity and to a variable thermal gradient, the lower crust can be hot and weak enough to flow and deform in a ductile way (McKenzie, 1978; Dewey, 1986). This variability of the lower crust composition and inheritance could lead to different rheological mechanisms but, so far, the internal structure of passive margins was poorly imaged, especially in magmarich passive margins where thick and reflective volcanic formations tend to hide the underlying signal. The existence of major ductile shear zones within the middle and lower crust of rifted margins has been suggested by numerical models (Hopper and Buck, 1996; Michon and Merle, 2003; Lavier and Manatschal, 2006; Huismans and Beaumont, 2011, 2014) but these shear zones have not yet been reported from present day passive margins. We present an unpublished industry seismic profile (ION Geophysical) across the Uruguayan magma-rich passive margin that provides high quality images of the intruded lower continental crust. The data present significant features that we interpret in favor of low-angle asymmetrical ductile shear at the base of the continental crust. By analogy with field and map examples, we determine a top to the continent sense of shear that is consistent with the kinematics of low-angle normal faults, dipping toward the continent, that controls the geometries of the Seaward Dipping Reflectors (SDR) formation.

\section{Geological setting}

The study area is located offshore the coast of Uruguay, in the Punta del Este sub-basin, in the southern tip of the Pelotas basins (Stica et al., 2014) - Fig. 1A. The present-day structure of the Uruguay Margin results from the break-up of Gondwana and subsequent opening of the South Atlantic Ocean during the Late Jurassic-Early Cretaceous (e.g.: Rabinowitz and LaBrecque, 1979; Gladczenko et al., 1997). In contrast to the magma-poor margins lying farther north in the Santos, Campos and Espirito Santo basins, the study area is characterized by thick wedges of SDR (up to $8 \mathrm{~km}$ ) and is devoid of post-rift salt deposits (Stica et al., 2014; Franke et al., 2007). The intense magmatic activity responsible for the SDR formation is related to the thick lava flows of the Parana Large Igneous Province (LIP - Gibson et al., 2006). Equivalent traps on the Namibian conjugate margin and continent are known as the Etendeka LIP (Turner et al., 1994). Both tabular traps and associated SDR wedges on the South American and South African margins once constituted the South
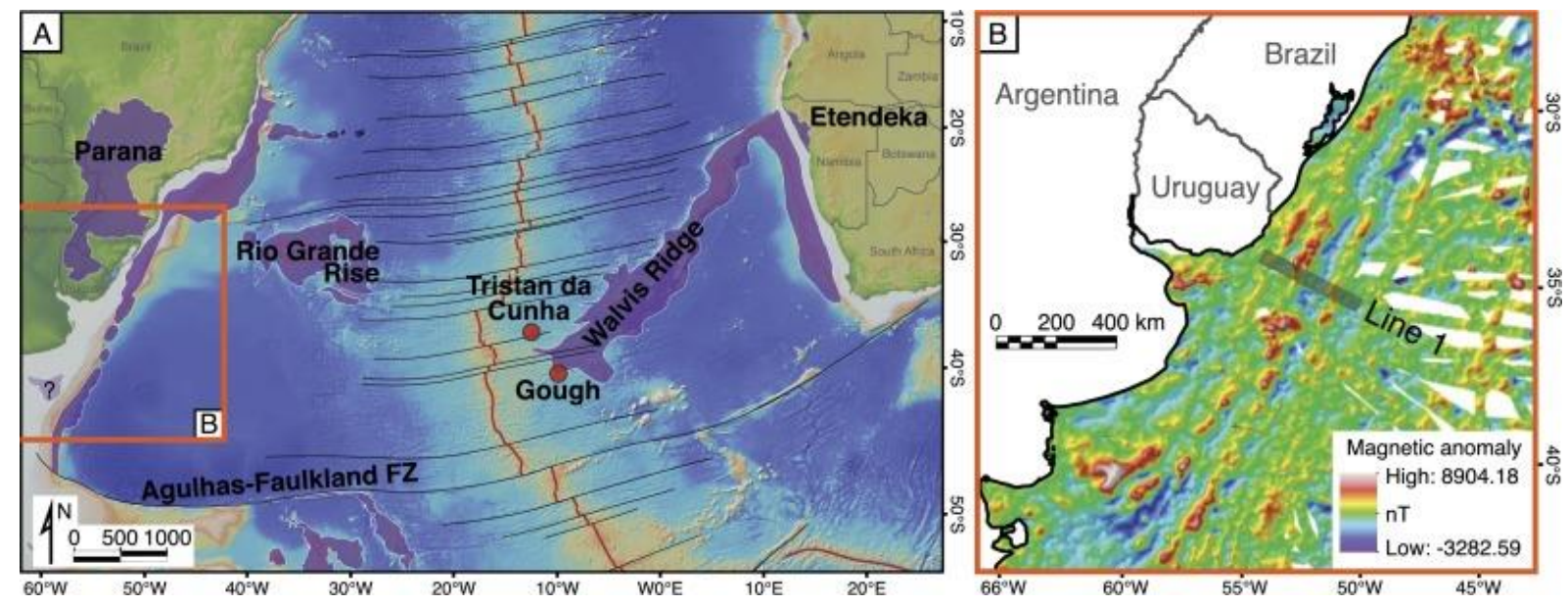

Fig. 1. A: Regional map of the southern Atlantic Ocean modified from Gladczenko et al. (1997), Stica et al. (2014) and Soto et al. (2011). B: Magnetic anomaly map of the study area on the Uruguayan 
passive margin after Maus et al. (2009). Discontinuous SDR patches appear as strong positive magnetic anomalies (red and white)

\section{Data and interpretation}

The seismic profile used in this paper belongs to ION's Uruguay SPAN deep reflection seismic dataset delivered in 2013 (Fig. 2). The ca. $350 \mathrm{~km}$-long profile presented in Fig. 2 gives a remarkable overview of the margin from an unextended $33 \mathrm{~km}$-thick continental crust to a well-established 6 to $8 \mathrm{~km}$-thick oceanic crust. The profile shows several SDR wedges lying on continental blocks and tilted by continentward-dipping normal faults. The SDR are observed as far as the Continent-Ocean transition.
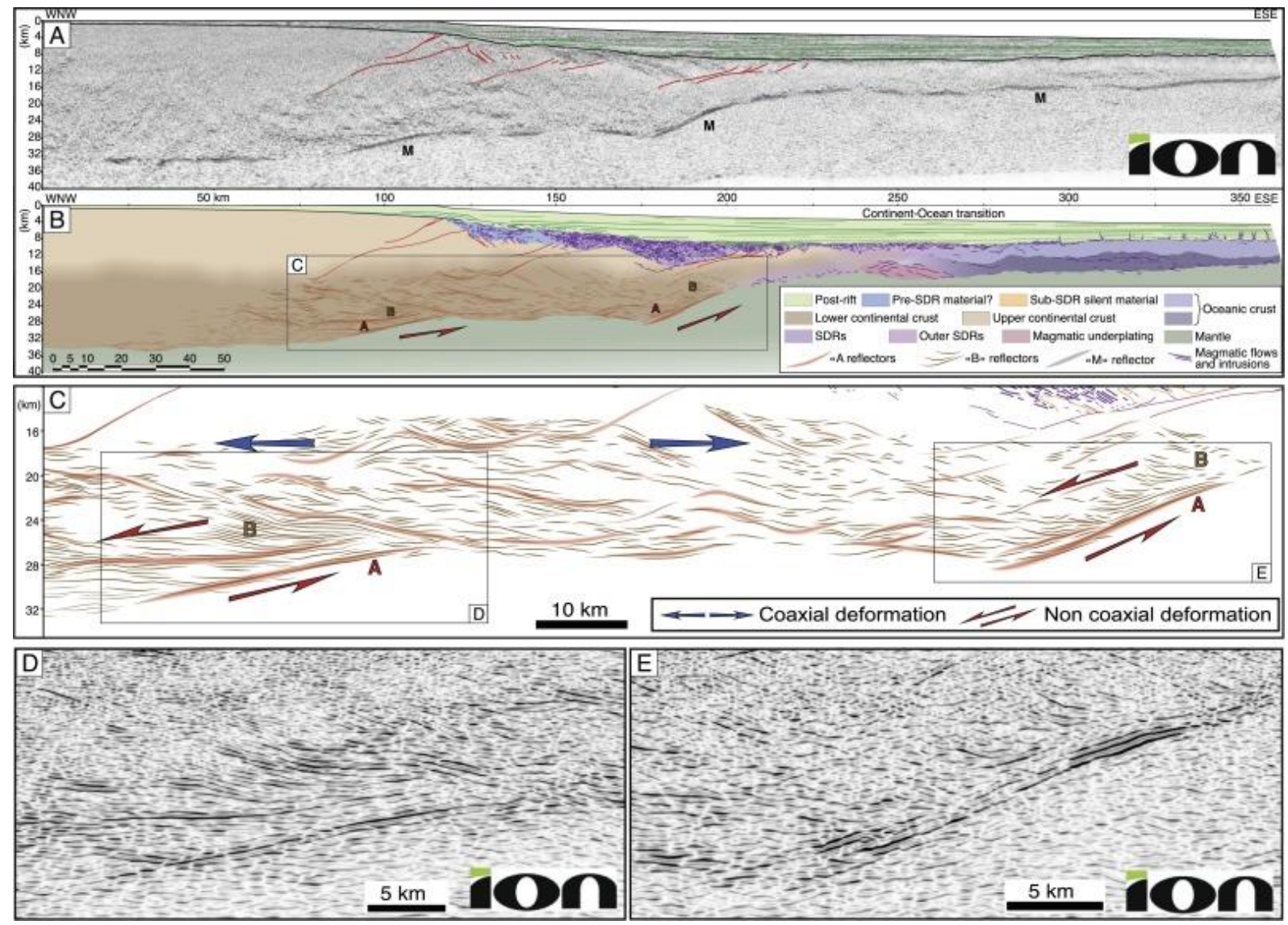

Fig. 2. A: Seismic reflection profile across the Uruguayan volcanic margin and its interpretation (B). C: interpreted close-up of the lower crust. D and $\mathrm{E}$ : details of the base of the continental crust presenting strong reflectors interpreted as typical shear patterns.

The prominent $\mathbf{M}$ reflector is located at depth ranging from $33 \mathrm{~km}$ below the continent to 16 $\mathrm{km}$ in the continent-ocean transition. On profile 1, the necking zone is divided into two shallow-dipping upward-convex ramps with one flat in-between. The two ramps concentrate the strongest seismic reflectors (Fig. 2). The dip of the $\mathbf{M}$ reflector ranges from $25^{\circ}$ toward the continent at its maximum to $0^{\circ}$ at the tip of the two ramps of the $\mathbf{M}$ reflector. 
The upper part of the continental crust is relatively transparent whereas the lower part of the continental crust shows a strong reflective pattern. In the lower crust, we distinguish two main groups of reflectors (Fig. 2B and C). The A reflectors are thick and continuous; some can be followed without any interruption on length of several tenths of kilometers. They are often superimposed on $\mathbf{M}$ reflectors.

A second group of reflectors (B reflectors in Fig. 2B and C) dipping toward the ESE (oceanward) is widely distributed in the lower crust. These 5 to $10 \mathrm{~km}$-long reflectors are slightly curved and tend to flatten and merge with A reflectors when approaching them. The amount and intensity of $\mathbf{B}$ reflectors seems to vary in strength along the profiles, they are notably abundant above the two upward inflexions of the $\mathbf{M}$ reflector.

The continental crust located between the uppermost crust and the very reflective lower crust presents a variable reflectivity. The reflectors are not as thick and continuous as they are at the base of the crust. Furthermore, the pattern drawn by these reflectors is more symmetrical with reflective A markers that seem to undulate with a $5 \mathrm{~km}$ to $10 \mathrm{~km}$ wavelength and circa $4 \mathrm{~km}$ vertical amplitude.

\section{Discussion}

\subsection{A crustal-scale shear zone imaged by seismic reflection}

The depth and geometry of the $\mathbf{M}$ reflector is consistent with the Moho drawn by Soto et al. (2011) in the area. This Moho is clearly marked and shows a staircase-geometry with two gently continentward-dipping ramps separated by a more silent domain.

Together, A and $\mathbf{B}$ reflectors draw a pattern that strongly resembles the ones observed in ductile shear zones of various scales (Fig. 3). The most characteristic feature calling for an analogy with ductile shear zones is the sigmoidal geometry of B reflectors when approaching A reflectors. Among many other examples, similar patterns are reported from the Great Slave Lake shear zone (Hanmer, 1988); the South Armorican Shear Zone (Gumiaux et al., 2004; Augier et al., 2010 - Fig. 3c and d); from the Bongolava-Ranotsara shear zone in southern Madagascar (Martelat et al., 2000 - Fig. 3e) or from the Pernambuco shear zone (Vauchez et al., 1995 - Fig. 3f). The A reflectors can be compared to the ductile shear planes whereas the $\mathbf{B}$ reflectors are evocative of planes and objects deflected by the ductile deformation and parallelized to the shear bands. The numerous $\mathbf{B}$ reflectors observed in the lower crust present sigmoidal shapes evocative of the pattern observed in metamorphic foliations close to ductile shear zones (Ramsay, 1980). 

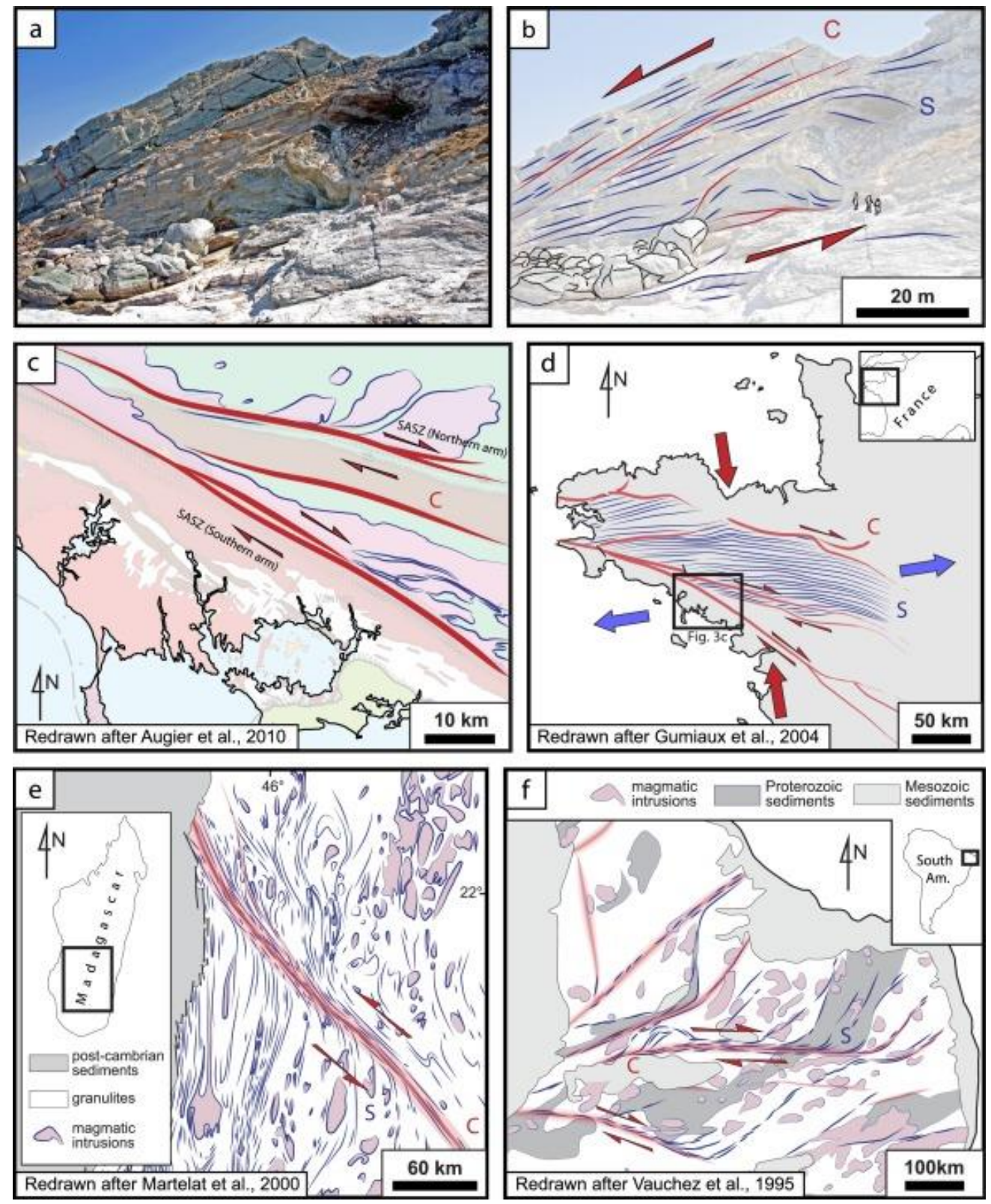

Fig. 3. Field and map examples of ductile shear zones at outcrop scale (a, $b$ - Tinos Island, Greece) and regional scale (c, $d$, e and f). Independently of the scale, these examples show patterns resembling those of Fig. 2D and $\mathrm{E}$ with lithological variations and schistosity (S) merging and parallelizing to long and continuous shear planes (C).

On many seismic profiles acquired around the world, it is common to observe a bright, apparently laminated lower crust (e.g.: Matthews, 1986). Strong reflections observed at the base of the crust are contrasting with the often less reflective appearance of the crystalline upper crust and upper mantle. Several authors demonstrated that both extensional and contractional mylonitic shear zones are reflective and can be traced over several kilometers on seismic reflection profiles (e.g.: Jones and Nur, 1984). Some of these can be used as kinematic indicators and allow deciphering between domains that underwent a dominant coaxial versus non-coaxial deformation (Torvela et al., 2013). 
From the relationships between the shear planes (reflectors $\mathbf{A}$ ) and the deformed sigmoidal layering (reflectors B) we can infer a top-to-the continent sense of shear (Fig. 2C). The general asymmetry of the ductile deformation and the shear sense deduced from our observations are consistent with the dip and offset of the continentward-dipping normal faults that affect the upper crust. Together, they indicate a deformation dominated by a simple shear toward the continent at the scale of the whole continental crust (Pindell et al., 2014). Such a sense of shear indicates a top-to-the continent movement of the crust relative to the mantle that can be interpreted in at least two ways, depending upon the localization of decoupling levels in the continental lithosphere. Either there is a weak crust-mantle coupling (Fig. 4 left), or the mantle is sufficiently coupled to the lower crust so that the mantle is able to drag the lower crust from below the margin and extract it toward the ocean (Fig. 4 right).
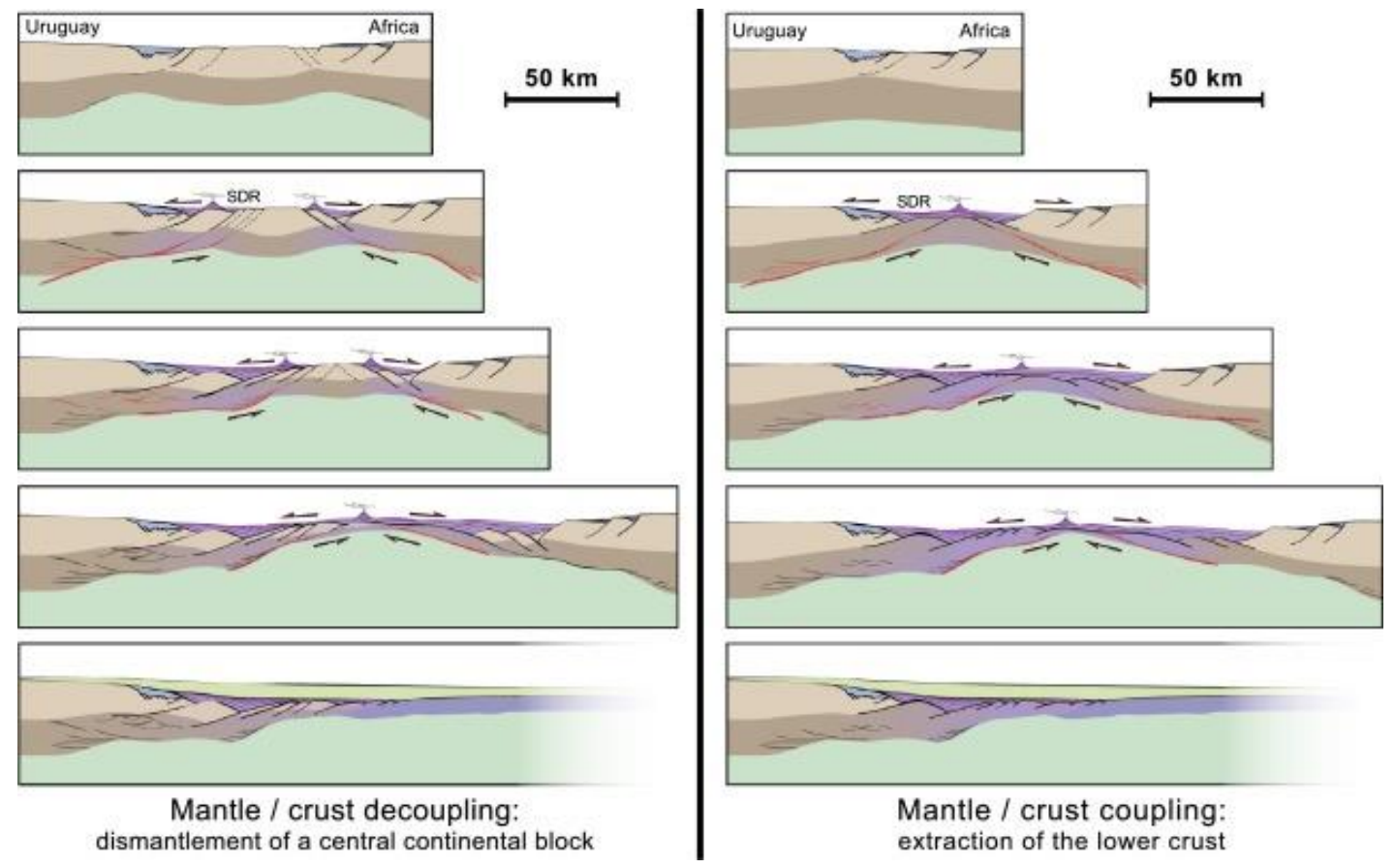

Fig. 4. Two scenarios for the formation of the continentward-dipping normal faults and evolution of the Uruguayan margin (this study) and conjugate South African volcanic margin (after Blaich et al., 2013). Left: The SDR prisms develop over tilted blocks formed at the expense of a central block (block " $C$ " of Geoffroy et al., 2015). In that case we expect sediments and upper crust to be present below the lava flows. Right: The SDR prisms develop over crustal slices extracted from each side of the rift toward a central discontinuity. In that case we rather expect to find endogenic crustal rocks below the SDR.

At intermediate depths, and in the flat between the two ramps, some shear zones are also probably imaged, but they present an anastomosed pattern indicating the coexistence of conjugate shear zones with alternating senses of shear. Such geometry evocative of boudinage indicates an important co-axial component of deformation (Gapais et al., 1987). However, these reflectors are not as clear as the ones observed and discussed above and should hence be considered with caution. 


\subsection{Origin of lower crustal reflectivity}

In our case, it is unclear whether the sheared objects responsible for the $\mathbf{B}$ reflectors are constituted of deformed pre-existing material or syn-tectonic intrusive material. Nevertheless, we can propose several hypotheses regarding their nature:

\subsubsection{Sheared pre-existing compositional heterogeneities of the lower crust}

Based on the interpretation of the high electric conductivity of the deep crust, some authors have suggested that the existence of free water could account for the layering imaged in the lower crust (e.g.: Matthews, 1986; Meissner and Wever, 1992; Guerri et al., 2015). However, for Yardley and Valley (1997) in the case of a deep stable crust, the water is consumed by retrograde metamorphism and there can be no free connected fluid phase (water or brine) available in the lower crust. In contrast, in the case of the deep crust of an active plate margin undergoing prograde metamorphism, one may envisage a liberation of fluids (e.g.: muscovite + quartz $=\mathrm{K}$-feldspar + kyanite $+\mathrm{H}_{2} \mathrm{O}$ ), at the disputable condition that the lower crust would have to be constituted of hydrated minerals. For Green et al. (1990) the layered reflections are the result of inherited velocity discontinuities at highly strained contacts between varying lithologies. The composition of the lower crust in this region is however unknown and we have no idea of its original lithological heterogeneity before rifting. The long tectonic history of the South American crust may have led to a lithological stratification that, once sheared could explain the seismic reflectors of Fig. 2C, D and E.

\subsubsection{Shear-induced anisotropy as a cause of reflectivity}

One alternative is that the sheared reflectors correspond to new foliation formed during shearing, leading to a true S-C mylonite geometry (Berthé et al., 1979). Laboratory experiments on a mylonitic gabbro and its protolith revealed that the seismic anisotropy significantly increases with mylonitic deformation but that the resulting anisotropy is not strong enough to give rise to a detectable reflection on a seismic profile (Burlini et al., 2005). Furthermore, the P-waves velocity is more temperature-dependent in the mylonite than in the protolith. As a consequence, the impedance contrast between protolith and mylonite is likely to be detected on seismic profiles acquired along crustal section presenting low geothermal gradients, but not in environment characterized by the high thermal gradients expected during continental rifting.

Mainprice and Casey (1990) calculated the seismic properties expected for quartz mylonites and obtained good correlations between lattice preferred orientations and Vp anisotropy (aaxes = flow direction in $\mathrm{Qtz}=\min \mathrm{Vp} / \mathrm{c}$-axes $=\max \mathrm{Vp}$ ). Velocities are usually slower perpendicular to foliation and faster parallel to foliation (Jones and Nur, 1982). This indicates that ductile fault zones are not strong seismic reflectors. Ji et al. (1997) obtained similar results in sheared granulites. For Shaocheng et al. (1993), the seismic reflectivity is controlled at first order by the lithology whereas fabric-induced anisotropy is a secondary factor capable of both enhancing and decreasing seismic reflectivity. It should be noted however that the association a strong fabric formed by shearing and the differentiation of a layering because of metamorphic reactions during the same process at the scale of several tens of kilometers has not been tested by experimental data. 
For some authors, the layering and anastomosed reflectors observed in the lower crust are due to a combination of ductile foliation accentuated by intrusive mafic or ultramafic bodies (Matthews, 1986; Warner, 1990). This interpretation fits peculiarly well the case presented here since the massive fluxes of magmatic material responsible for the SDR formation are known to account for dramatic volumes of underplating and intrusive magmatism within the continental crust underlying the SDRs (Geoffroy, 2005). Note however that a similar heterogeneity could also result from older orogenic events, leading to alternating acidic and mafic compositions.

Although the shear induced anisotropy and the presence of free-water are not favored in previous studies (e.g. Burlini et al., 2005; Yardley and Valley, 1997), the exact origin of the B reflectors cannot be clearly deciphered. However, we believe that the three possible causes of reflections (deformed varying lithologies, shear induced anisotropy/metamorphic recrystallization and syn-tectonic intrusion) would result in shear patterns resembling those exemplified and redrawn in Fig. 2C, D and E.

\subsection{Two alternative scenarios}

The geometry of reflectors in the lower crust and the attitude of normal faults in the upper crust of the Uruguay margin show a component of simple shear distributed across the entire continental crust, thus showing that the mantle has been extracted from below the margin. This is true at the scale of one margin but at the scale of the entire rift and the two conjugate margins, the finite geometry regime seems more symmetrical. Previous works indeed show that the Uruguayan and African conjugate margins are symmetrical (Gladczenko et al., 1997; Blaich et al., 2013; Mello et al., 2013). Based on our observation of the Uruguayan margin and on the assumption that the seismic reflectors described above have a physical significance in terms of finite deformation, we propose two speculative scenarios for the formation of the conjugate Uruguay-South Africa volcanic margins (Fig. 4). Scenario 4A involves a strong decoupling in the middle crust disconnecting the continentward-dipping normal faults from the lower crustal shear zones that preferentially localize along the Moho discontinuity because of the rheological contrast between mantle peridotites and lower crustal material. A central continental block is progressively dismantled ("C" block of Geoffroy et al., 2015). The continentward-dipping normal faults that control the SDR formation migrate sequentially toward the center of the extended domain. In this scenario, one may expect to find remnants of the continental crust abandoned in fully oceanic domain (e.g. slivers of continental crust beneath southeast Iceland - Torsvik et al., 2015; Seychelles arc-type granitoids - Ashwal et al., 2002). An important consequence of this scenario is that the basement supporting the SDR deposits would be constituted of upper continental crust including pre-rift sediments.

Scenario 4B instead involves more or less continuous shear zones from the upper crustal continentward-dipping normal faults to the lower crustal shear zones, allowing an extraction of fragments of mid- to lower continental crust, and ultimately mantle, from below the margin. This process implies a stronger coupling between the mantle and the base of the crust across the basal shear zones. The two steeper ramps observed along the Moho would then be the major accommodation zones of this exhumation, and the deformation in-between would be less non-coaxial with more symmetrical boudinage. In that case, we may expect a higher thermal gradient and a basement constituted of mid- to lower crust below the SDR wedges. If 
the scenario of Fig. 4 right is right, further models of passive margins will have to take into consideration the possible horizontal drag of the crust by the underlying mantle.

\subsection{General implications for the behavior of the continental crust during rifting}

Several numerical approaches suggest an important ductile shear within the mid- to lower continental crust during crustal thinning (Harry and Sawyer, 1992; Michon and Merle, 2003; Lavier and Manatschal, 2006; Van Avendonk et al., 2009). However, in these models, most of the ductile deformation is localized in the middle crust and the authors consider a strong lower crust in which the deformation is more localized (e.g. Van Avendonk et al., 2009). Our new findings suggest that the lower crust of at least some rifted margins may have behaved in a rather weak and ductile way. Such a ductile behavior of the lower crust in extensional settings was already suggested by the quantitative modeling of Hopper and Buck (1996) and Huismans and Beaumont (2011, 2014 - model type 2) but their physical existence had not been revealed until now. In the case of the Uruguayan volcanic margin, the weakness of the lower crust is probably strongly related to high heat flow above the mantle plume and associated important syn-tectonic magmatic activity that resulted in underplating and dense impregnation of the crust by magmatic melts (Franke et al., 2006; Hirsch et al., 2009). Magmas may have induced a further thermal and mechanical weakening during their emplacement (Ayalew, 2011; Schmeling and Wallner, 2012). Weakening of the lower crust may result in the development of a relative motion of the crust with respect to the mantle with a Couette-like flow, rather than a Poiseuille flow, at the base of the continental crust (Hopper and Buck, 1996). The finite geometry shown on the Uruguay margin shows a clear case of depth-dependent extension with differential motion between the various levels of the lithosphere. A similar case is shown with the Gulf of Lion margin where the lower crust and mantle are extracted from below the margin (Jolivet et al., 2015). The Uruguay example shows a similar configuration but the internal geometry of the shear zones accommodating the differential motion is clearly displayed when it is only inferred in the Gulf of Lion. The mechanics of rifting leading to depth-dependent extension has been explored by means of forward numerical modeling by Huismans and Beaumont $(2011,2014)$. The pattern of the depth-dependent extension (removal of either the crust or the lithospheric mantle) is controlled in these models by the strength of the middle and lower crusts that acts on the degree of coupling between the upper and lower lithosphere. The different models shown in Huismans and Beaumont (2014) are symmetrical at the scale of the two conjugate margins with either mantle exhumation or mantle removal, lower crust exhumation or lower crust removal but the case where a simple shear component is distributed through the whole crust with the same shear sense and an extraction of the lower crust and mantle is not treated. The Uruguay margin and the Gulf of Lion however show that this situation is pertinent and should be explored by numerical modeling. The adequate kinematic boundary conditions have yet to be found and a possible role of a basal drag by the flowing mantle to be explored.

The weakness of the lower crust would then depend upon the heat flow and with the abundance of magmatic melts intruding the crust of volcanic passive margins, such ductile deformation of the lower crust may hence not be generalized to all kinds of passive margins and may be a specificity of volcanic margins. The existence of a top-to-the continent sense of shear at the scale of the whole crustal section deserves to be explored in other volcanic rifted margins worldwide, since it satisfactorily explains the continentward dipping normal faults responsible for the oceanward tilt of the SDR. 


\section{Conclusion}

An unpublished seismic profile across the volcanic rifted margin of Uruguay shows patterns strongly evocative of ductile shearing deformation in the lower continental crust. The top-tothe continent sense of shear deduced from this pattern is in agreement with the continentwarddipping normal faults controlling the SDR deposition. These observations suggest simple shear-dominated deformation at the scale of the whole continental crust and indicative of a relative movement between the mantle and the continental crust. We propose two alternative scenarios involving either a mid-crustal decoupling and low coupling at the base of the crust, or a stronger coupling at the crust-mantle interface leading to the lateral extraction of mid- to lower crustal material.

\section{Acknowledgments}

We are grateful to ION and Total E\&P Uruguay for providing the exceptional dataset. R. Huismans, L. Lavier and an anonymous reviewer greatly helped the authors by reviewing the manuscript. This work was funded by Total through a postdoc grant to C. Clerc. This paper is a contribution of the ERC Advanced Research Grant RHEOLITH (grant agreement No. 290864), of Institut Universitaire de France and Labex VOLTAIRE.

\section{References}

Ashwal et al., 2002

L.D. Ashwal, D. Demaiffe, T.H. TorsvikPetrogenesis of Neoproterozoic granitoids and related rocks from the Seychelles: the case for an Andean-type arc origin

J. Petrol., 43 (1) (2002), pp. 45-83

Augier et al., 2010

Augier, R., Turillot, B., Hallégouët, B., Van-Vliet-Lanoë, B., Thinon, I., Menier, D., 2010. Vannes ST Gildas-de-Rhuys feuille 417, BRGM geological map.

Ayalew, 2011

D. AyalewThe relations between felsic and mafic volcanic rocks in continental flood basalts of Ethiopia: implication for the thermal weakening of the crust

Geol. Soc. (Lond.) Spec. Publ., 357 (1) (2011), pp. 253-264, 10.1144/SP357.13

Berthé et al., 1979

D. Berthé, P. Choukroune, P. JegouzoOrthogneiss, mylonite and non coaxial deformation of granites: the example of the South Armorican Shear Zone

J. Struct. Geol., 1 (1) (1979), pp. 31-42, 10.1016/0191-8141(79)90019-1

Blaich et al., 2013

O.A. Blaich, J.I. Faleide, F. Tsikalas, A.C. Gordon, W. MohriakCrustal-scale architecture and segmentation of the South Atlantic volcanic margin

Geol. Soc. (Lond.) Spec. Publ., 369 (1) (2013), pp. 167-183, 10.1144/SP369.22 
Burlini et al., 2005

L. Burlini, L. Arbaret, G. Zeilinger, J.-P. BurgHigh-temperature and pressure seismic properties of a lower crustal prograde shear zone from the Kohistan Arc, Pakistan

Geol. Soc. (Lond.) Spec. Publ., 245 (1) (2005), pp. 187-202, 10.1144/GSL.SP.2005.245.01.09

Dewey, 1986

J.F. DeweyDiversity in the lower continental crust

Geol. Soc. (Lond.) Spec. Publ., 24 (1) (1986), pp. 71-78, 10.1144/GSL.SP.1986.024.01.08

Franke et al., 2006

D. Franke, S. Neben, B. Schreckenberger, A. Schulze, M. Stiller, C.M. KrawczykCrustal structure across the Colorado Basin, offshore Argentina

Geophys. J. Int., 165 (3) (2006), pp. 850-864, 10.1111/j.1365-246X.2006.02907.x

Franke et al., 2007

D. Franke, S. Neben, S. Ladage, B. Schreckenberger, K. HinzMargin segmentation and volcano-tectonic architecture along the volcanic margin off Argentina/Uruguay, South Atlantic

Mar. Geol., 244 (1-4) (2007), pp. 46-67, 10.1016/j.margeo.2007.06.009

Gapais et al., 1987

D. Gapais, P. Bale, P. Choukroune, P. Cobbold, Y. Mahjoub, D. MarquerBulk kinematics from shear zone patterns: some field examples

J. Struct. Geol., 9 (5-6) (1987), pp. 635-646, 10.1016/0191-8141(87)90148-9

Geoffroy, 2005

L. GeoffroyVolcanic passive margins

C. R. Géosci., 337 (16) (2005), pp. 1395-1408, 10.1016/j.crte.2005.10.006

Geoffroy et al., 2015

L. Geoffroy, E.B. Burov, P. WernerVolcanic passive margins: another way to break up continents

Nature Scientific Reports SREP-15-07695A. Accepted manuscript

(2015)

Gibson et al., 2006

S.A. Gibson, R.N. Thompson, J.A. DayTimescales and mechanisms of plume-lithosphere interactions: ${ }^{40} \mathrm{Ar} /{ }^{39} \mathrm{Ar}$ geochronology and geochemistry of alkaline igneous rocks from the Paraná-Etendeka large igneous province

Earth Planet. Sci. Lett., 251 (1-2) (2006), pp. 1-17, 10.1016/j.epsl.2006.08.004

Gladczenko et al., 1997 
T.P. Gladczenko, K. Hinz, O. Eldholm, H. Meyer, S. Neben, J. SkogseidSouth Atlantic volcanic margins

J. Geol. Soc., 154 (3) (1997), pp. 465-470, 10.1144/gsigs.154.3.0465

Green et al., 1990

A. Green, B. Milkereit, J. Percival, A. Davidson, R. Parrish, F. Cook, W. Geis, W. Cannon, D. Hutchinson, G. West, R. ClowesOrigin of deep crystal reflections: seismic profiling across high-grade metamorphic terranes in Canada

Tectonophysics, 173 (1-4) (1990), pp. 627-638, 10.1016/0040-1951(90)90250-C

Guerri et al., 2015

M. Guerri, F. Cammarano, J.A.D. ConnollyEffects of chemical composition, water and temperature on physical properties of continental crust

Geochem. Geophys. Geosyst., 16 (7) (2015), pp. 2431-2449, 10.1002/2015GC005819

Gumiaux et al., 2004

C. Gumiaux, J.P. Brun, D. GapaisStrain removal within the Hercynian Shear Belt of Central Brittany (western France): methodology and tectonic implications

Geol. Soc. (Lond.) Spec. Publ., vol. 224 (2004), pp. 287-305, 10.1144/GSL.SP.2004.224.01.18 Hanmer, 1988

S. HanmerGreat Slave Lake Shear Zone, Canadian Shield: reconstructed vertical profile of a crustal-scale fault zone

Tectonophysics, 149 (3-4) (1988), pp. 245-264, 10.1016/0040-1951(88)90176-X

Harry and Sawyer, 1992

D.L. Harry, D.S. SawyerA dynamic model of extension in the Baltimore Canyon trough region

Tectonics, 11 (2) (1992), pp. 420-436, 10.1029/91TC03012

Hirsch et al., 2009

K.K. Hirsch, K. Bauer, M. Scheck-WenderothDeep structure of the western South African passive margin - results of a combined approach of seismic, gravity and isostatic investigations

Tectonophysics, 470 (1-2) (2009), pp. 57-70, 10.1016/i.tecto.2008.04.028

Hopper and Buck, 1996

J.R. Hopper, W.R. BuckThe effect of lower crustal flow on continental extension and passive margin formation

J. Geophys. Res., Solid Earth, 101 (B9) (1996), pp. 20175-20194, 10.1029/96JB01644

Huismans and Beaumont, 2011 
R. Huismans, C. BeaumontDepth-dependent extension, two-stage breakup and cratonic underplating at rifted margins

Nature, 473 (7345) (2011), pp. 74-78, 10.1038/nature09988

Huismans and Beaumont, 201

R.S. Huismans, C. BeaumontRifted continental margins: the case for depth-dependent extension

Earth Planet. Sci. Lett., 407 (2014), pp. 148-162, 10.1016/j.epsl.2014.09.032

Ji et al., 1997

S. Ji, C. Long, J. Martignole, M. SalisburySeismic reflectivity of a finely layered, granulitefacies ductile shear zone in the southern Grenville Province (Quebec)

Tectonophysics, 279 (1-4) (1997), pp. 113-133, 10.1016/S0040-1951(97)00133-9

Jolivet et al., 2015

L. Jolivet, C. Gorini, J. Smit, S. LeroyContinental breakup and the dynamics of rifting in backarc basins: the gulf of Lion margin

Tectonics, 34 (4) (2015), Article 2014TC003570, 10.1002/2014TC003570

Jones and Nur, 1982

T. Jones, A. NurSeismic velocity and anisotropy in mylonites and the reflectivity of deep crystal fault zones

Geology, 10 (5) (1982), pp. 260-263, 10.1130/0091-7613(1982)10<260:SVAAIM>2.0.CO;2 Jones and Nur, 1984

T.D. Jones, A. NurThe nature of seismic reflections from deep crustal fault zones

J. Geophys. Res., Solid Earth, 89 (B5) (1984), pp. 3153-3171, 10.1029/JB089iB05p03153

Lavier and Manatschal, 2006

L.L. Lavier, G. ManatschalA mechanism to thin the continental lithosphere at magma-poor margins

Nature, 440 (7082) (2006), pp. 324-328, 10.1038/nature04608

Mainprice and Casey, 1990

D. Mainprice, M. CaseyThe calculated seismic properties of quartz mylonites with typical fabrics: relationship to kinematics and temperature

Geophys. J. Int., 103 (3) (1990), pp. 599-608, 10.1111/j.1365-246X.1990.tb05674.x

Martelat et al., 2000

J.-E. Martelat, J.-M. Lardeaux, C. Nicollet, R. RakotondrazafyStrain pattern and late Precambrian deformation history in southern Madagascar

Precambrian Res., 102 (1-2) (2000), pp. 1-20, 10.1016/S0301-9268(99)00083-2 
Matthews, 1986

D.H. MatthewsSeismic reflections from the lower crust around Britain

Geol. Soc. (Lond.) Spec. Publ., 24 (1) (1986), pp. 11-21, 10.1144/GSL.SP.1986.024.01.03

Maus et al., 2009

S. Maus, U. Barckhausen, H. Berkenbosch, N. Bournas, J. Brozena, V. Childers, F. Dostaler, J.D. Fairhead, C. Finn, R.R.B. von Frese, C. Gaina, S. Golynsky, R. Kucks, H. Lühr, et al.EMAG2: a 2arc min resolution Earth Magnetic Anomaly Grid compiled from satellite, airborne, and marine magnetic measurements

Geochem. Geophys. Geosyst., 10 (8) (2009), Article Q08005, 10.1029/2009GC002471

McKenzie, 1978

D. McKenzieSome remarks on the development of sedimentary basins

Earth Planet. Sci. Lett., 40 (1) (1978), pp. 25-32, 10.1016/0012-821X(78)90071-7

Meissner and Wever, 1992

R. Meissner, T. WeverThe possible role of fluids for the structuring of the continental-crust Earth-Sci. Rev., 32 (1-2) (1992), pp. 19-32, 10.1016/0012-8252(92)90010-Q

Mello et al., 2013

M.R. Mello, N.C.D.A. Filho, A.A. Bender, S.M. Barbanti, W. Mohriak, P. Schmitt, C.L.C.D. JesusThe Namibian and Brazilian southern South Atlantic petroleum systems: are they comparable analogues?

Geol. Soc. (Lond.) Spec. Publ., 369 (1) (2013), pp. 249-266, 10.1144/SP369.18

Michon and Merle, 2003

L. Michon, O. MerleMode of lithospheric extension: conceptual models from analogue modeling

Tectonics, 22 (4) (2003), p. 1028, 10.1029/2002TC001435

Mohn et al., 2012

G. Mohn, G. Manatschal, M. Beltrando, E. Masini, N. KusznirNecking of continental crust in magma-poor rifted margins: evidence from the fossil Alpine Tethys margins

Tectonics, 31 (1) (2012), 10.1029/2011TC002961

Müntener et al., 2000

O. Müntener, J. Hermann, V. TrommsdorffCooling history and exhumation of lower-crustal granulite and upper mantle (Malenco, Eastern Central Alps)

J. Petrol., 41 (2) (2000), pp. 175-200, 10.1093/petrology/41.2.175

Pindell et al., 2014 
J. Pindell, R. Graham, B. HornRapid outer marginal collapse at the rift to drift transition of passive margin evolution, with a Gulf of Mexico case study

Basin Res., 26 (6) (2014), pp. 701-725, 10.1111/bre.12059

Rabinowitz and LaBrecque, 1979

P.D. Rabinowitz, J.L. LaBrecqueThe Mesozoic South Atlantic Ocean and evolution of its continental margins

J. Geophys. Res., 84 (B11) (1979), pp. 5973-6002, 10.1029/JB084iB11p05973

Ramsay, 1980

J.G. RamsayShear zone geometry: a review

J. Struct. Geol., 2 (1-2) (1980), pp. 83-99, 10.1016/0191-8141(80)90038-3

Schmeling and Wallner, 2012

$\mathrm{H}$. Schmeling, $\mathrm{H}$. WallnerMagmatic lithospheric heating and weakening during continental rifting: a simple scaling law, a 2-D thermomechanical rifting model and the East African Rift System

Geochem. Geophys. Geosyst., 13 (8) (2012), Article Q08001, 10.1029/2012GC004178

Shaocheng et al., 1993

J. Shaocheng, M.H. Salisbury, S. HanmerPetrofabric, P-wave anisotropy and seismic reflectivity of high-grade tectonites

Tectonophysics, 222 (2) (1993), pp. 195-226, 10.1016/0040-1951(93)90049-P

Soto et al., 2011

M. Soto, E. Morales, G. Veroslavsky, H. de Santa Ana, N. Ucha, P. RodríguezThe continental margin of Uruguay: crustal architecture and segmentation

Mar. Pet. Geol., 28 (9) (2011), pp. 1676-1689, 10.1016/i.marpetgeo.2011.07.001

Stica et al., 2014

J.M. Stica, P.V. Zalán, A.L. FerrariThe evolution of rifting on the volcanic margin of the Pelotas Basin and the contextualization of the Paraná-Etendeka LIP in the separation of Gondwana in the South Atlantic

Mar. Pet. Geol., 50 (2014), pp. 1-21, 10.1016/j.marpetgeo.2013.10.015

Torsvik et al., 2015

T.H. Torsvik, H.E.F. Amundsen, R.G. Trønnes, P.V. Doubrovine, C. Gaina, N.J. Kusznir, B. Steinberger, F. Corfu, L.D. Ashwal, W.L. Griffin, S.C. Werner, B. JamtveitContinental crust beneath southeast Iceland

Proc. Natl. Acad. Sci., 112 (15) (2015), pp. E1818-E1827, 10.1073/pnas.1423099112

Torvela et al., 2013 
T. Torvela, J. Moreau, R.W.H. Butler, A. Korja, P. HeikkinenThe mode of deformation in the orogenic mid-crust revealed by seismic attribute analysis

Geochem. Geophys. Geosyst., 14 (4) (2013), pp. 1069-1086, 10.1002/ggge.20050

Turner et al., 1994

S. Turner, M. Regelous, S. Kelley, C. Hawkesworth, M. MantovaniMagmatism and continental break-up in the South Atlantic: high precision ${ }^{40} \mathrm{Ar}-{ }^{39} \mathrm{Ar}$ geochronology

Earth Planet. Sci. Lett., 121 (3-4) (1994), pp. 333-348, 10.1016/0012-821X(94)90076-0

Van Avendonk et al., 2009

H.J.A. Van Avendonk, L.L. Lavier, D.J. Shillington, G. ManatschalExtension of continental crust at the margin of the eastern Grand Banks, Newfoundland

Tectonophysics, 468 (1-4) (2009), pp. 131-148, 10.1016/j.tecto.2008.05.030

Vauchez et al., 1995

A. Vauchez, S. Neves, R. Caby, M. Corsini, M. Egydio-Silva, M. Arthaud, V. AmaroThe Borborema shear zone system, NE Brazil

J. South Am. Earth Sci., 8 (3-4) (1995), pp. 247-266, 10.1016/0895-9811(95)00012-5

Warner, 1990

M. WarnerBasalts, water, or shear zones in the lower continental crust?

Tectonophysics, 173 (1-4) (1990), pp. 163-174, 10.1016/0040-1951(90)90214-S

Yardley and Valley, 1997

B.W.D. Yardley, J.W. ValleyThe petrologic case for a dry lower crust

J. Geophys. Res., Solid Earth, 102 (B6) (1997), pp. 12173-12185, 10.1029/97JB00508 